\title{
50 YEARS OF THE MACEDONIAN ACADEMY OF SCIENCES AND ARTS 1967-2017 AND 48 YEARS OF PUBLISHING THE JOURNAL PRILOZI (CONTRIBUTIONS) OF MASA
}

\author{
Momir Polenakovic ${ }^{1}$, Nada Pop-Jordanova ${ }^{1}$, Zoran Gucev $^{2}$ \\ ${ }^{1}$ Macedonian Academy of Sciences and Arts, Skopje, Republic of Macedonia \\ ${ }^{2}$ University Children's Hospital, Medical Faculty, Skopje, Republic of Macedonia
}

Corresponding author: Momir Polenakovic, Macedonian Academy of Sciences and Arts, Bul. Krste Misirkov 2, Skopje, Republic of Macedonia, email: momir@manu.edu.mk

\begin{abstract}
Papers on medical subjects have been published since the first issue of the journal Prilozi in 1969, totalling a number of of 957 (nine hundred and fifty seven) papers have been published in Prilozi. Two hundred and twenty nine cover subjects on natural sciences and mathematics, and 728 (seven hundred and twenty eight) subjects on medical sciences. So far, 2017 No. XXXVIII-2, 622 (six hundred and twenty two) papers published in Prilozi are in Pubmed. Prilozi is published three times a year and it is covered by the following services: Baidu Scholar, Case, Celdes, CNKI Scholar (China National Knowledge Infrastructure), CNPIEC, DOAJ (Directory of Open Access Journals), EBSCO (relevant databases), EBSCO Discovery Service, Elsevier - SCOPUS, Google Scholar, J-Gate, JournalTOCs, KESLI-NDSL (Korean National Discovery for Science Leaders), Naviga (Softweco), Primo Central (ExLibris), Publons, PubMed, ReadCube, ResearchGate, SCImago (SJR), Summon (Serials Solutions/ProQuest), TDNet, Ulrich's Periodicals Directory/ulrichsweb WanFang Data, WorldCat (OCLC).
\end{abstract}

Keywords: journal Prilozi (Contributions), PubMed, citation

The Macedonian Academy of Sciences and Arts (MASA) this year celebrates a jubilee 50 years of existence and work [1].

Today we live in a world of science.

This global knowledge-based society is founded on the results obtained from scientific research. The data from basic research in developed countries contribute in quite a substantial manner to the newly added economic value. One of the main reasons for underdevelopment in South Eastern Europe (SEE) is certainly the low or non-existent contribution of scientific research in the newly added economic value. This to a great extent is due to the perception of the political elites which simply lack the insight into the crucial importance of science in reference to development. In the long term this leads to societies in which there are distortions in the understanding of the most basic values.

Academic publishing has experienced tremendous growth: so far there are at least 50 million scientific articles. Interestingly, publishing in developing countries has experienced a rate of growth higher than in the developed countries. However, this is not the case with the Balkan countries [2].

The publishing activity plays a very important part in the work of MASA.

The scientific journal PRILOZI (Contributions) is the departmental periodical.

The journal Prilozi (Contributions, Section of Medical Sciences of the MASA) in the period 1969-1980 the journal was published under the title: 
„Prilozi. Oddelenie za prirodo-matematicki nauki“, MANU (Contributions, Section of Natural Sciences and Mathematics, MASA). The first Editor-in-chief was Academician B. Popov, and D. Arsov and Gj. Filipovski were members of the Editorial board.

Since 1980, the journal has been published as a separate publication under the title Prilozi (Contributions), Section of Biological and Medical Sciences of the Macedonian Academy of Sciences and Arts. It publishes original scientific works, research reports to be the journal of the Section of Medical Sciences and as of 2013 the journal has been published in a new design in A4 format, thrice a year.

So far, 2017 No. XXXVIII-2, 622 (six hundred and twenty two) papers published in Prilozi are in $\mathrm{Pu}-$ bmed. A total of 957 (nine hundred and fifty seven) papers have been published in Prilozi: two hundred and twenty nine) covering subjects on natural sciences and mathematics, and 728 (seven hundred and twenty eight) focusing on medical sciences subjects.

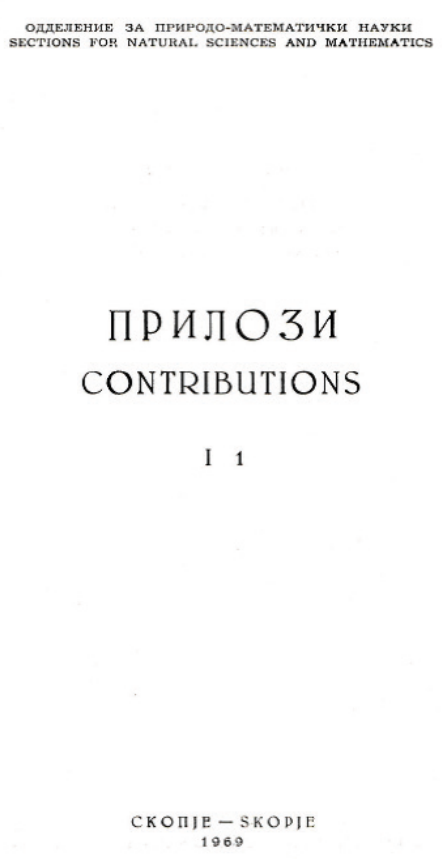


Rainer Ingo Peter Kotz (Austria), Yucel Kanpolat (Turkey) Harald Mischak (Germany), Ferid Murad (USA), Ljubisa Rakic (Serbia), Vladislav Stefanovic (Serbia), Antonie Skoklev (Serbia), Draga Toncheva (Bulgaria), Felix Unger (Austria), Andrzej Wiecek (Poland).

Prilozi is covered by the following services: Baidu Scholar, Case, Celdes, CNKI Scholar (China National Knowledge Infrastructure), CNPIEC, DOAJ (Directory of Open Access Journals), EBSCO (relevant databases), EBSCO Discovery Service, Elsevier - SCOPUS, Google Scholar, J-Gate, JournalTOCs, KESLI-NDSL (Korean National Discovery for Science Leaders), Naviga
- improvement of editorial standards, in order to promote professionalism in medical editing through education, self-criticism and self-regulation;

- research encouragement on the principles and practice of medical editing (6).

We are looking forward to successful future publications.

Acknowledgement to Goce Aleksoski for his assistance in the preparation of the paper.

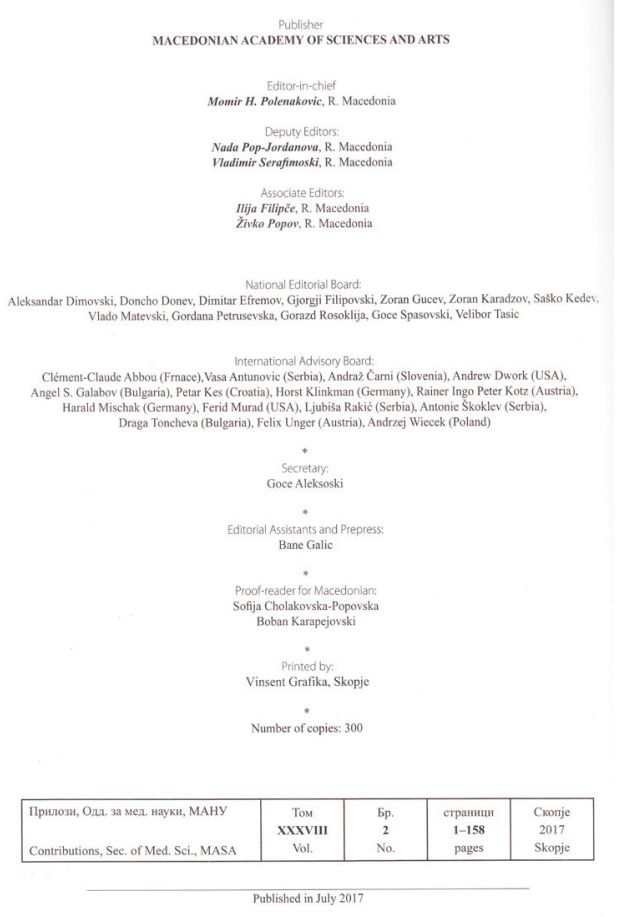

Figure 2. Prilozi - the last issue, 2017, XXXVIII-2

(Softweco), Primo Central (ExLibris), Publons, PubMed, ReadCube, ResearchGate, SCImago (SJR), Summon (Serials Solutions/ProQuest), TDNet, Ulrich's Periodicals Directory/ulrichsweb WanFang Data, WorldCat (OCLC).

The papers published in Prilozi have contributed to the affirmation of our medical sciences and related sciences in the world [5].

We should foster the goals of the World Association of Medical Editors - WAME, which include:

- facilitation of worldwide cooperation and communication among editors of peer-reviewed medical journals;

\section{REFERENCES}

1. Fiti Taki: On the eve of the great jubilee -50 years of the Macedonian Academy of Sciecnes and Arts 1967-2017 Prilozi (Contributions), Sec. Med. Sci. MASA, XXXVIII, 2, p. 5-8 (2017)

2. Polenakovic M., Gucev Z. Publishing integrity and good practices in editing in biomedicine. CONTRIBUTIONS. Sec. Med. Sci., XXXV 3, 2014, 11-16

3. Polenakovic M. Forty years since the foundation of the Macedonian Academy of Sciences and Arts (MASA) and 27 years of publishing the journal 
Prilozi (Contributions), Oddelenie za bioloski i medicinski nauki (Section of biological and medical sciences) of the MASA Prilozi (Contributions), Sec. Biol. Med. Sci., MASA, XXVIII, 2, p. 5-10 (2007).

4. Polenakovic M., Danevska L. Medical journals in the Republic of Macedonia after the Second World
War Prilozi (Contributions), Sec. Biol. Med. Sci., MASA, XXXII, 2, p. 11-31 (2011).

5. Polenakovic M. New form of the journal Prilozi (Contributions) of the Macedonian Academy of Sciences and Arts, Section of Medical Sciences. CONTRIBUTIONS. Sec. Med. Sci., XXXIV 1, 2013, 5-6.

\title{
Резиме
}

\section{0 ГОДИНИ МАКЕДОНСКА АКАДЕМИЈА НА НАУКИТЕ И УМЕТНОСТИТЕ 1967-2017 И 48 ГОДИНИ ОД ОБЈАВУВАЊЕТО НА СПИСАНИЕТО ПРИЛОЗИ НА МАНУ}

\author{
Момир Поленаковиќ ${ }^{1}$, Нада Поп-Јорданова ${ }^{1}$, Зоран Гучев ${ }^{2}$ \\ ${ }^{1}$ Македонска академија на науките и уметностите, Скопје, Република Македонија \\ ${ }^{2}$ Клиника за детски болести, Медицински факултет, Скопје, Република Македонија
}

Славиме 50 години од Македонската академија на науките и уметностите 1967-2017 и 48 години од издавањето на списанието ПРИЛОЗИ на МАНУ

Трудови со медицинска тематика се објавуваат од првиот број на списанието Прилози во 1969 година. Вкупно 957 (деветстотини педесет и седум) трудови се објавени во Прилози. Двесте дваесет и девет со тематика од природно-математичките науки и 728 (седумстотини дваесет и осум) со тематика од медицинските науки. Досега, 2017 бр. XXXVIII-2, 622 (шестотини дваесет и два) труда објавени во Прилози се на Пабмед. Прилози излегува трипати годишно и е опфатено од следниве бази: Baidu Scholar, Case, Celdes, CNKI Scholar (China National Knowledge Infrastructure), CNPIEC, DOAJ (Directory of Open Access Journals), EBSCO (relevant databases), EBSCO Discovery Service, Elsevier SCOPUS, Google Scholar, J-Gate, JournalTOCs, KESLI-NDSL (Korean National Discovery for Science Leaders), Naviga (Softweco), Primo Central (ExLibris), Publons, PubMed, ReadCube, ResearchGate, SCImago (SJR), Summon (Serials Solutions/ProQuest), TDNet, Ulrich's Periodicals Directory/ulrichsweb WanFang Data, WorldCat (OCLC).

Клучни зборови: списание Прилози, Пабмед, цитираност 